\title{
MP-9S ipari manipulátor anyagmozgatási és selejtezési feladatok ellátása ipari környezetben
}

\section{MP-9S Industrial Manipulator Handling and Scrapping Tasks in Industrial Environments}

\author{
Józsa Roland Osszián, ${ }^{1}$ Erdei Timotei István, ${ }^{2}$ Kapusi Tibor Péter, ${ }^{3}$ Tóth Szabolcs, ${ }^{4}$ \\ Husi Géza ${ }^{5}$ \\ Debreceni Egyetem Müszaki Kar, Debrecen, Magyarország, \\ 1 immortalskeleton01@gmail.com \\ ${ }^{2}$ timoteierdei@eng.unideb.hu \\ ${ }^{3}$ kapu-si.tibor@zimbra.inf.unideb.hu \\ 4szabolcs978@gmail.com \\ ${ }^{5}$ husigeza@eng.unideb.hu
}

\begin{abstract}
The main goal of the project was to carry out a handling task using a color sensor and thermal sensor, as well as an industrial robotic unit. The selection by color made it possible to represent the sub-process of the production of a sample, where each color can be matched to the corresponding or rejected product. The function of the thermal sensor is to show the delay function for the pro-cess, which occurs when the product does not reach a point in the process at the wrong tempera-ture and needs cooling between the two workflows. The thermal sensor and color sensor were pro-grammed using the ATmega microprocessor, while the manipulator was controlled with industrial PLC. The completed project will serve educational purposes in training for students.
\end{abstract}

Keywords: RTT, industrial manipulator, handling, colour sensor, heat sensor, PLC, ATmega328P, MP-9S.

\section{Összefoglalás}

A projekt során anyagmozgatási feladat elvégzése volt a fő cél, ami színérzékelő és hőérzékelő szenzor segítségével történt, valamint egy ipari robotegységgel. A szín szerinti válogatás lehetővé tette egy mintagyártás alfolyamatának reprezentálását, ahol az egyes színek a megfelelő, illetve se-lejt terméknek feleltethetőek meg. A hőérzékelő szenzor feladata, hogy bemutatásra kerüljön a kés-leltetési funkció a folyamat számára, ami akkor lép fel, ha az adott termék nem a megfelelő hőmér-sékleten éri el a folyamat egy pontját, és hülésre van szüksége a két munkafolyamat között. A hőér-zékelő és a színérzékelő programozása ATmega mikroprocesszor alkalmazásával történt, míg a ma-nipulátor vezérlése ipari PLC-vel. A megvalósult projekt oktatási célokat fog szolgálni a képzésben a hallgatók számára.

Kulcsszavak: RTT, ipari manipulátor, anyagmozgatás, színérzékelő, hőérzékelő, PLC, ATmega328P, MP-9.

\section{Bevezetés}

Az anyagmozgatási feladatok a mindennapi életünk részévé váltak, így érdemes foglalkozni a tömeggyártás során fellépő hibákkal. Ennek reprezentálása komplex, így a problémát mind- enképp ipari környezetben kellett megvalósítani, amihez a Debreceni Egyetem Mechatronikai Tanszék, Cyber-Physical \& Intelligent Robot Systems Laboratory szolgált [1] 


\section{A megfelelő technológia kiválasztása}

A projekt során egy PLC és Atmega mikrokontroller, illetve színérzékelő és hőérzékelő szenzor került bevonásra. A feladat fő részét képző MP$9 S$ gépegységet eredetileg autóipari gyárakban alkalmazták [2]. Az MP-9S az Ipar 4.0 elvárásainak megfelelően felújításra került, és lehetségessé vált, PLC-, illetve mikrokontroller-alapú vezérlés is, valamint alkalmazása HMI-hálózaton keresztüli vezérlés céljából [3].

\section{MP-9S manipulátor múködésének ismertetése}

Az MP-9S manipulátor (1. ábra) pneumatikus működtetésủ és 3 szabadságfokkal rendelkezik. Fémházának első részében a megfogó fej mozgását biztosító kar helyezkedik el. Hátsó részében 8 darab elektropneumatikus szelep a vezetékeket összegyüjtő 2 darab csatlakozóval. Az MP-9S robot kinemati-

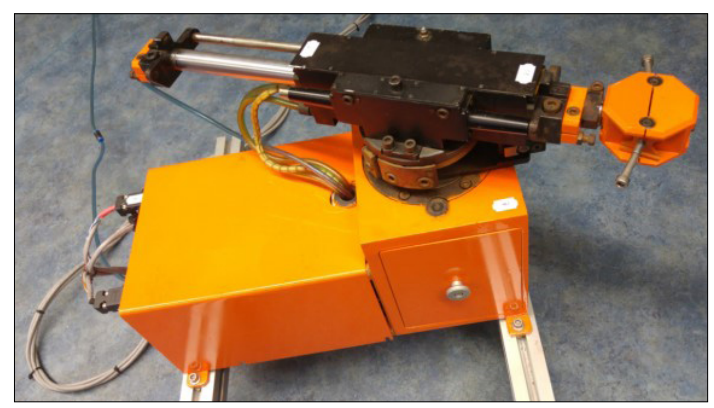

kai lánca (amely a 2. ábrán látható), egyértelműen reprezentálja, hogy ez egy háromtengelyes RTTtípusú gépegység. A tengelyek mindegyikét pneumatikus segédenergiával működtetjük.

\section{Alkalmazott érzékelők és programo- zásuk}

\subsection{TCS230-M Színérzékelő modul}

A 4 fehér LED segítségével megvilágított terület színmérését végzi el a TCS230-típusú szenzor. (3. ábra) A fényszenzor RGBW-színeket képes mérni, melyeket frekvenciává alakít.

A vezérléshez Arduino NANO került felhasználásra. Az Arduino egy nyílt forráskódú fej- lesztői platform, mely az ATmega mikrokontroller család tagja [4]. Az Arduino NANO fő része az ATmega328P mikrokontroller, amely 8 bites, és RISC-alapú (1. táblázat).

1. táblázat. ATmega328P chip jellemzői [4]

\begin{tabular}{|l|c|}
\hline Programmemória-típus & Flash \\
\hline Programmemória & $32 \mathrm{~KB}$ \\
\hline CPU-sebesség & $20 \mathrm{MIPS}$ \\
\hline Digitális PWM-pinek & $6 \mathrm{PWM}$ \\
\hline Hőmérséklet-tartomány & $-40+85^{\circ} \mathrm{C}$ \\
\hline Müködési tartomány & $1.8-5.5 \mathrm{~V}$ \\
\hline Lábak száma & 32 \\
\hline
\end{tabular}

1. ábra. Az MP-9S manipulátor

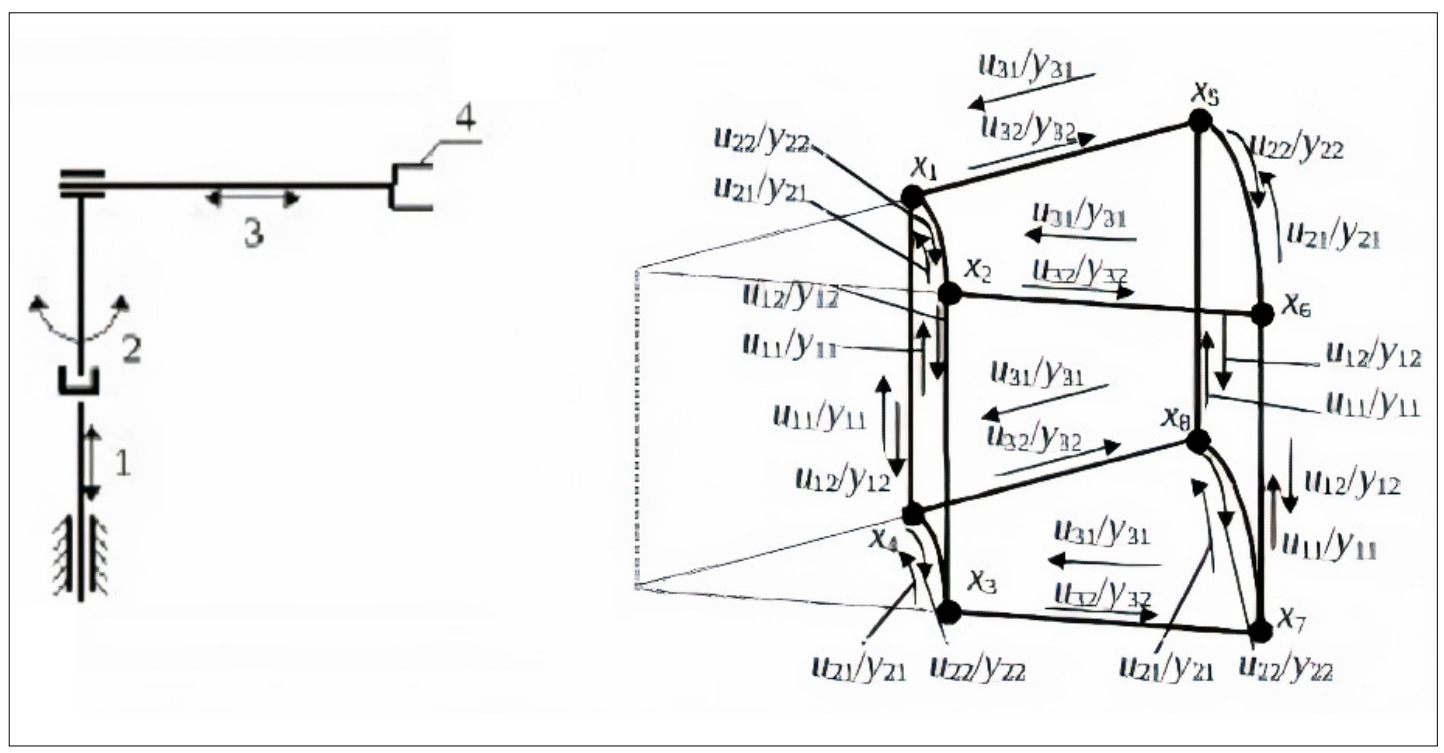




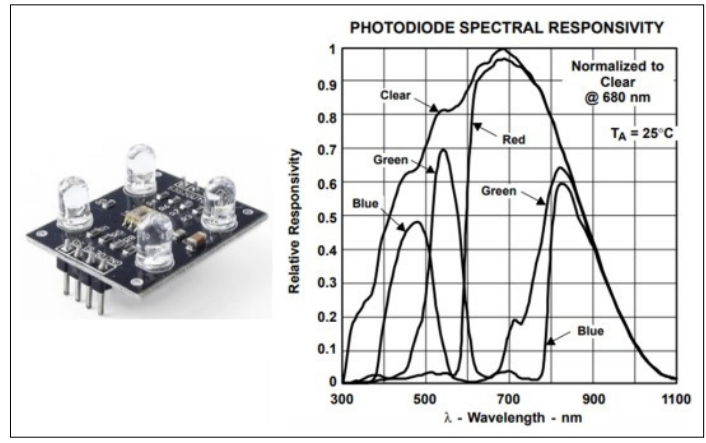

3. ábra. TCS230-M színérzékelő modul és PCB-je [6, 7]

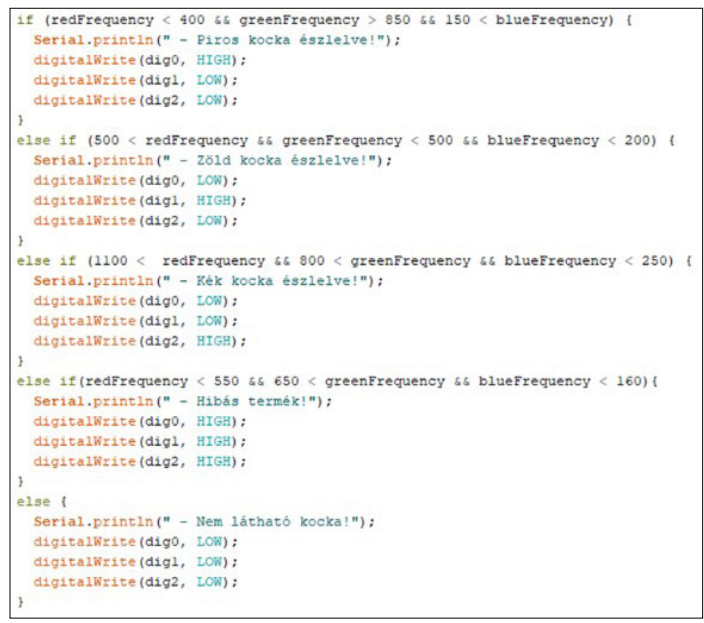

4. ábra. Programrészlet: Frekvenciák összehasonlítása

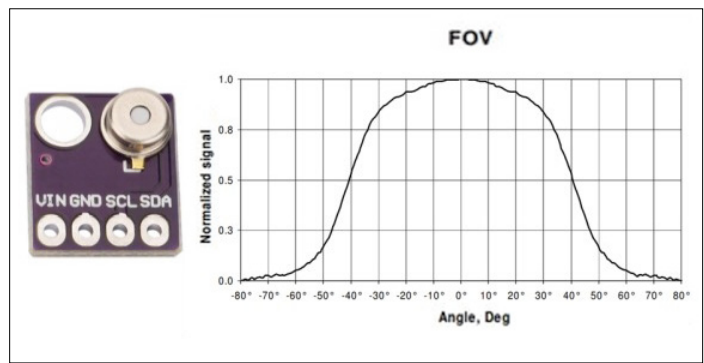

5. ábra. MLX90615 infra hőérzékelő és Field of viewértékek [8]

2. táblázat. MLX90615-es hőérzékelő adatai [8]

\begin{tabular}{|l|l|c|}
\hline $\begin{array}{c}\text { Hőmérséklet } \\
\left.\text { [ }{ }^{\circ} \mathrm{C}\right]\end{array}$ & Eszközhőfok & $-40+85$ \\
\cline { 2 - 3 } & Mérendő objektum hőfok & $-40+115$ \\
\hline Mérési szórás [ $\left.{ }^{\circ} \mathrm{C}\right]$ & $0.5(0+50)$ \\
\hline Kiolvasási pontosság [ ${ }^{\circ} \mathrm{C}$ ] & 0.02 \\
\hline Múködésifeszültség-tartomány [V] & 3.3 \\
\hline
\end{tabular}

A szenzorhoz írt program (részletek a 4. ábrán) első lépéseként deklarálásra kerül a lábkiosztás, majd a PLC-be futó pin. Majd a megfelelő színfrekvenciákat is deklaráljuk.

\subsection{MLX90615 infravörös hőérzékelő szenzor}

A hőérzékelő szerepét az MLX90614 (5. ábra) infravörös hőmérsékletszenzor tölti be.

$10,5 \times 13 \times 9,6 \mathrm{~mm}$ méretekkel rendelkezik. Adatai a 2. táblázatban vannak feltüntetve.

A korábban megírt színérzékelő program került bővítésre (6. ábra), annak érdekében, hogy a MLX90615 hőérzékelő szenzort is alkalmazni tudjuk. Első lépésében maga a kész fájl került beolvasásra, majd a PLC-be futó pinek deklarálása történt meg, legvégül a kimenetek kerültek elnevezésre.

\subsection{PLC \& ATmega328P szenzorok kapcso- lási rajza}

A kapcsolási rajz a 7. ábrán látható.

\section{Kockatartó}

A színérzékelő érzékelési távolsága $10 \mathrm{~mm}$-ig pontos, ezért szükség volt egy kockatartó 3D-s nyomtatására (8. ábra).

\section{MP-9S vezérlése ipari modicon M340 PLC-vel}

A robotegység vezérlését a Schneider Modicon M340 moduláris PLC használatával programoztuk [9]. A PLC program LD, azaz létradiagramban került megírásra (9. ábra) az MP-9S számára, amelyhez Unity Pro XL fejlesztői környezet került alkalmazásra.

\section{Következtetések}

A fentebb kitűzött célok elérésre kerültek. Az MP-9S ipari robotegység hő- és színérzékelő bevonásával képes az adott elemek megkülönböztetésére és azok szortírozására, annak megfelelően, hogy a kocka által reprezentált munkadarab hibás-e vagy sem.

\section{Köszönetnyilvánítás}

Köszönjük mindazoknak, akik részt vettek a projektben, kiváltképp Horváth Patrik Péternek és a Debreceni Egyetem, Műszaki Kar Mechatronikai Tanszékének.

A publikáció elkészítését az EFOP-3.6.1-16-201600022 számú projekt támogatta. A projekt az Európai Unió támogatásával, az Európai Szociális Alap társfinanszírozásával valósult meg. 


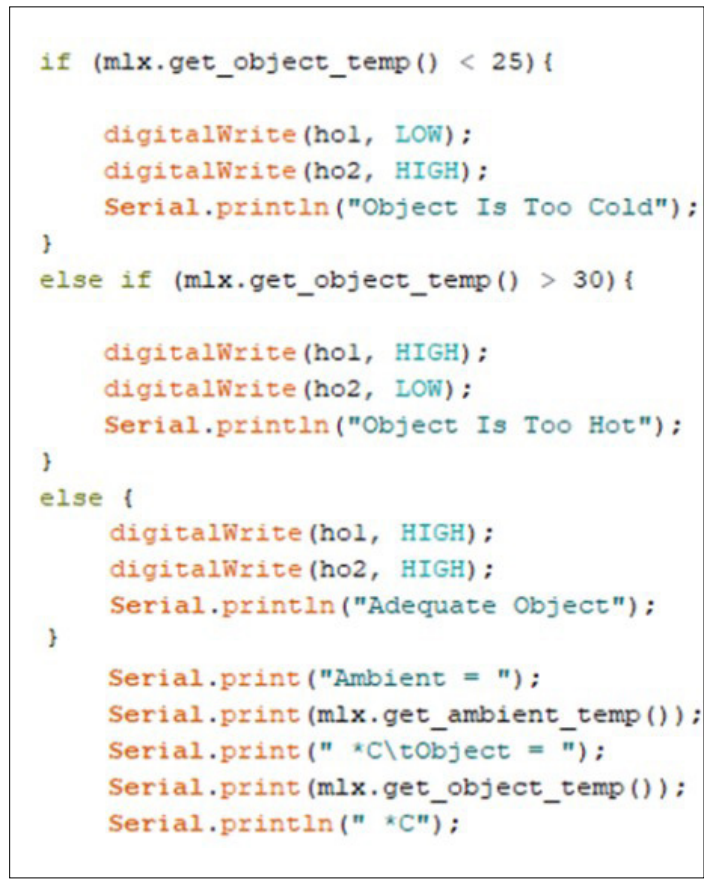

6. ábra. Hőérzékelő programrészlete

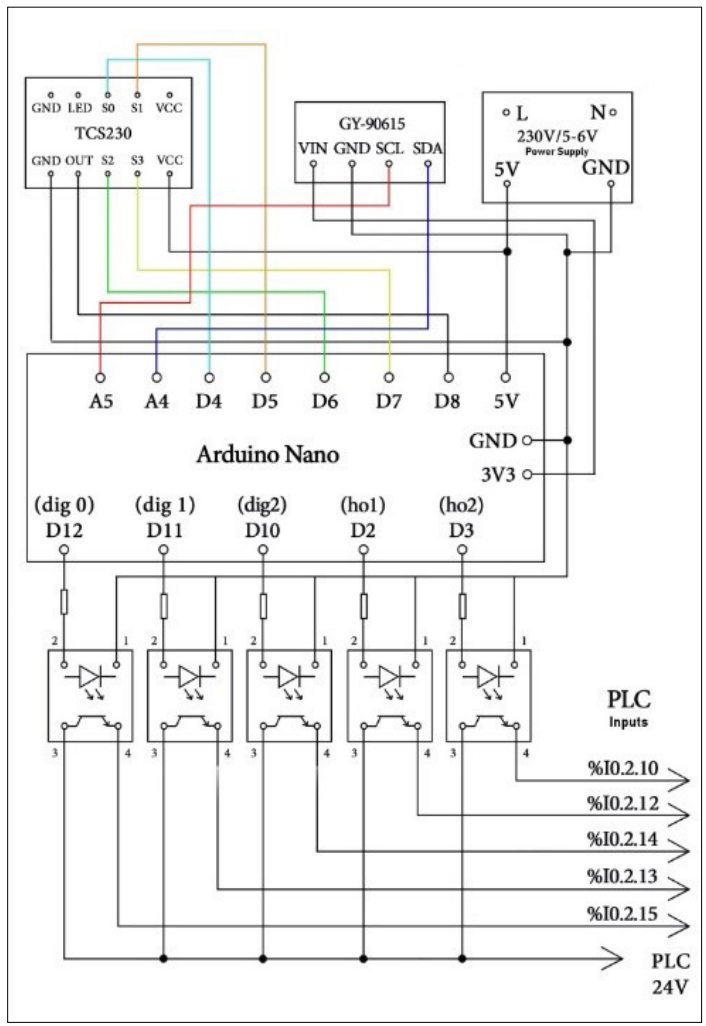

7. ábra. Kapcsolási rajz

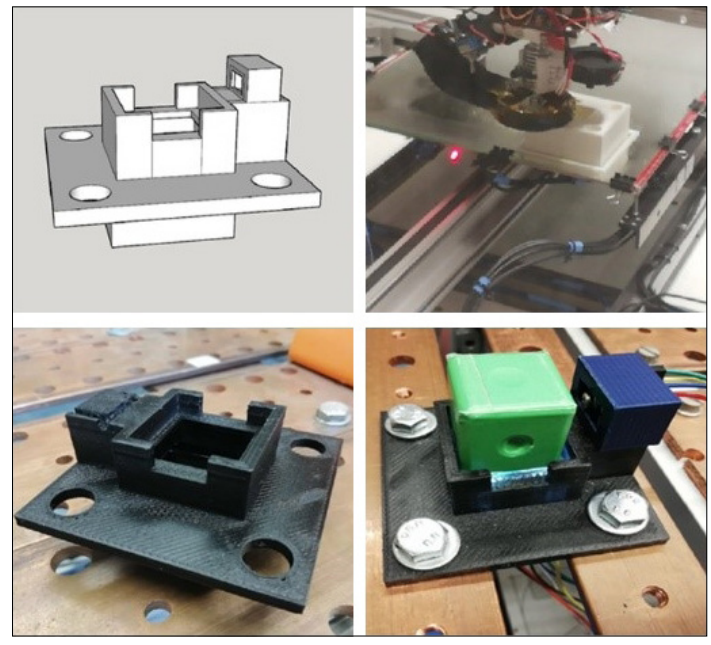

8. ábra. A kockatartó modellje és 3D nyomtatása

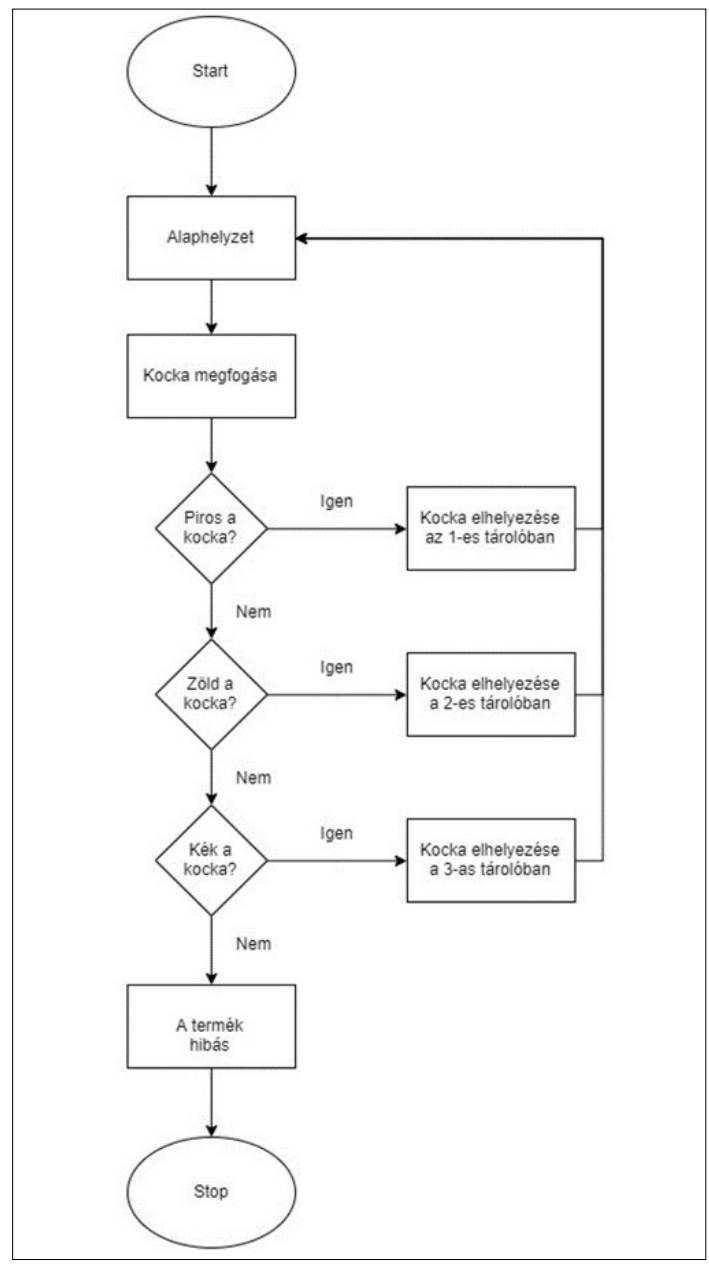

9. ábra. A PLC-program folyamatábrája 


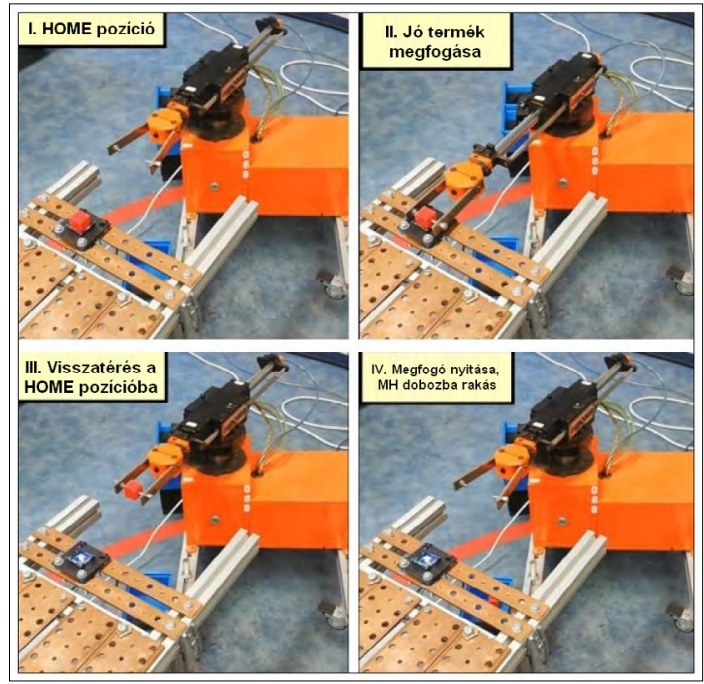

10. ábra. Az MP-9S manipulátor müködés közben

\section{Szakirodalmi hivatkozások}

[1] Husi G.: Introduction to Robot Technology. (TÁMOP-4.1.2.D-12/1/KONV-2012-0008) 2014.

[2] Popov A. K. A. : Az MP-9SZ ipari robot felépítése és programozása. Moszkva, 2005.

[3] Horváth P. P. , Erdei T. I., Husi G.: Restoration and PLC Control of a Material handling MP-9S Industrial Manipulator Platform. Annals Of The Oradea University. Fascicle of Management and Technological Engineering, XXIX (XIX), 2019/2(2) https://doi.org/10.15660/AUOFMTE.2019-2.3453
[4] Arduino NANO PCB. (accessed on: 01.11.2019) https://www.arduino.cc/en/uploads/Main/ArduinoNanoManual23.pdf

[5] V. Novgorod, MP-9S ipari robot programozása, 2005.

[6] TCS230 Datasheet. (accessed on: 01.10.2019) https://www.alldatasheet.com/datasheetpdf/ pdf/202765/TAOS/TCS230.html

[7] Hestore - TCS230-M Single-Supply Operation. (accessed on: 01.11.2019)

https://www.hestore.hu/prod_getfile.php?id=8628

[8] MLX90615-Datasheet-Melexis, (accessed on: 01. 11. 2020)

https://www.melexis.com//media/files/documents/ datasheets/mlx90615-datasheet-melexis.pdf

[9] Schinder Modicon M340, (accessed on: 01. 11. 2020)

https://www.se.com/hu/hu/product-range-presentation/1468-modicon-m340/\#tabs-top

[10] TCS230-M color light-to-frequency converter. (accessed on: 01.10.2019)

https://www.alldatasheet.com/datasheet-pdf/ pdf/96471/ETC/TCS230D.html

[11] Industrial PLC Programming. (accessed on: 01. 11. 2019) http://zeus.nyf.hu/ elat/PLC-k.pdf

[12] MLX90614 Non-Contact IR Temperature Sen-sor, (accessed on: 01.11.2019)

https://components101.com/sensors/melexis-mlx90614-contact-less-ir-temperature-sensor

[13] Erdei T. I., Husi G.: Singularity Measurement in the Cyber-Physical and Intelligent Robot Systems Laboratory. International Review of Applied Sciences and Engineering, 11/2. (2020) 82-87. https://doi.org/10.1556/1848.2020.20001

[14] Google SketchUP, (accessed on: 01. 11. 2020) https://www.sketchup.com/ 